\title{
Glucocorticoids Affect Male Testicular Steroidogenesis
}

\author{
Richard HAMPL ${ }^{1}$, Luboslav STÁRKA ${ }^{1}$ \\ ${ }^{1}$ Institute of Endocrinology, Prague, Czech Republic
}

Received July 29, 2019

Accepted October 2, 2019

\begin{abstract}
Summary
Through their receptors at each level of hypothalamo-pituitarygonadal axis glucocorticoid excess, either endogenous or administered or stress-induced, could affect steroid production in the testis and thus male fertility. The main ways by which glucocorticoids act are as follows: 1) Affecting gonadoliberin and LH synthesis and release through glucocorticoid receptors in hypothalamic neurons and pituitary gonadotropes. 2) By so far not clearly evidenced reduction of the number of $\mathrm{LH}$ receptors on the membrane of Leydig cells. 3) By affecting expression and function of steroidogenic enzymes in the testis. 4) By regulation of in situ access of glucocorticoid to its target cells in the testis. 5) By promotion Leydig cell apoptosis. The review provides a survey of physiological and molecular mechanisms staying behind these effects. It does not deal with the clinical effects of glucocorticoid treatment which would substantially exceed the scope of the pater.
\end{abstract}

\section{Key words}

Glucocorticoid • Stress • HPG axis • Leydig cell • Apoptosis

\section{Corresponding author}

R. Hampl, Institute of Endocrinology, Národní 8, 11694 Prague 1, Czech Republic. E-mail: rhampl@endo.cz

\section{Introduction}

Clinical experience as well as many experimental studies brought evidence that excess of glucocorticoids (GCs), either administered or stressinduced, impacts testicular function and thus male fertility (Hu et al. 2008, Whirledge and Cidlowski 2010, Nargund 2015, Witorsch 2016). In this review we tried to survey multiple physiological and molecular mechanisms staying behind these effects.

As documented in many situations, stress inhibits reproductive functions. An unusual example could be shown here. During five days' military training course for Norwegian male cadets with hard physical activity day and night and almost no sleep or food, a decrease was found in $\mathrm{LH}, \mathrm{FSH}$, prolactin and thyreotropin. A decrease was also found in androgens testosterone, dihydrotestosterone (DHT), androstenedione, dehydroepiandrosterone and 17 $\alpha$-hydroxyprogesterone, whereas dehydroepiandrosterone-sulfate increased twofold. The LH and FSH responses to gonadoliberin $(\mathrm{GnRH})$ intravenously were increased at the end of the course. This demonstrates enhanced pituitary reserves of gonadotropin, or, alternatively, increased sensitivity to GnRH stimulation and may be due to decreased hypothalamic secretion of $\mathrm{GnRH}$ during the course. The decreased DHT and testosterone levels were almost normalized after hCG stimulation, indicating a gonadotropin regulated decrease in testosterone secretion during the course. In spite of fairly weak correlation between the alteration in gonadotropins and androgens it is concluded that there is a major regulation of testicular androgen secretion during prolonged stress by the hypothalamo-pituitary axis. Psychogenic effect on the androgen levels could be demonstrated by the even more deep decease of androgens in a subgroup of cadets who were methodically under bullying of the officers (Opstadt 1992).

Many of these actions are mediated by glucocorticoid receptors (GR). Nuclear GR are present in almost all cells of the body, including receptors at each level of hypothalamo-pituitary-gonadal (HPG) axis. In addition, rapid non-genomic actions of GC should be 
considered (Dong et al. 2004). Most experimental data have been obtained on rodents, but the results are of importance also for human medicine since corticoids belong to mass used therapeutics and may affect considerably male fertility.

The main ways GCs utilize for affecting and regulation of testicular function may be summarized as follows: 1) By affecting gonadoliberin and LH synthesis and release through GR in hypothalamic neurons and pituitary lutropes. 2) By influencing the number of LH receptors on the membrane of Leydig cells through local GR. 3) By affecting expression and function of steroidogenic enzymes in the testis. 4) By regulation of in situ access of glucocorticoid to its target cells in the testis. 5) By promotion Leydig cell apoptosis.

\section{Glucocorticoid effect on GnRH and LH synthesis and release}

Testicular steroidogenesis is governed by hypothalamo-pituitary-gonadal axis (HPG), while glucocorticoid balance is maintained by hypothalamopituitary-adrenal (HPA) axis. In both instances the regulation takes advantage of negative as well as positive feed-back loops and thanks to receptors at each level, a cross talk exists between both axes. The signaling molecules of the HPG axis are able to modulate corticoid signaling and at the same time the hormones of the HPA axis, first of all corticosteroids, but also other stress hormones, influence the HPG axis (Oyola and Handa 2017, Acevedo-Rodriguez et al. 2018).

As early in seventies (Sakakura et al. 1975) demonstrated that glucocorticoid treatment of humans led to inhibition of luteinizing hormone secretion induced by synthetic gonadoliberin. Indirect evidence for GR-mediated inhibition of pituitary LH secretion by GC brought Briski et al. (1995) showing that GR antagonist RU486 attenuated the acute decline in circulating LH in stressed rats. Expression of GR was confirmed in mouse gonadotropes along with the finding that treatment with GC reduces GnRH-induced specific LH $\beta$ expression (Breen et al. 2012, Breen and Mellon 2014).

Recent discovery of hypothalamic kisspeptin and its partial antagonist gonadotropin-inhibitory hormone (GnIH)/RFamide-related peptide 3 (RFRP-3), revealed further common sites in both axes. These peptides differ in their hypothalamic localization and both regulate gonadoliberin secretion but in a different way: kisspeptin directly stimulates GnRH synthesis and release, while
RFRP-3 acts in both hypothalamus and pituitary by suppressing the release and synthesis of $\mathrm{GnRH}$ and gonadotropins. Kisspeptin and RFRP-3 expression and activity are decreased and increased by stress, respectively, pointing to the role of stress induced hormones, first of all glucocorticoids. Indeed, corticoliberin $(\mathrm{CRH})$, which is the driving factor of HPA axis is another potent inhibitor of GnRH secretion and on the hypothalamic neuron systems may influence kisspeptin signaling (Iwasa et al. 2018, AcevedoRodriguez et al. 2018).

The receptor for $\mathrm{GnIH}$ is the G protein-coupled receptor 147 (GPR147), which inhibits cAMP signaling. GnIH can inhibit gonadotropin synthesis and release by decreasing the activity of GnRH neurons as well as by directly inhibiting pituitary gonadotrope activity. GnIH and GPR147 can thus centrally suppress testosterone secretion and spermatogenesis by acting in the hypothalamic-pituitary-gonadal axis. GnIH and GPR147 are also expressed in the testis of birds and mammals, possibly acting in an autocrine/paracrine manner to suppress testosterone secretion and spermatogenesis. GnIH expression is also regulated by melatonin, stress, and social environment in birds and mammals (Ubuka et al. 2014)

\section{Effect of glucocorticoids on lutropin receptors in Leydig cells}

Stimulation of testicular steroidogenesis by lutropin is mediated by membrane G protein-coupled LH receptors (LHR). In an early study on hypophysectomized rats and testicular cell culture, treatment with dexamethasone or corticosterone led to decrease of testicular $\mathrm{LH} / \mathrm{hCG}$ receptor content as measured by $\left[{ }^{125} \mathrm{I}\right] \mathrm{hCG}$ binding assay. Some animals were also given concomitantly FSH to prevent the hypophysectomy-induced decrease in testicular functions (Bambino and Hsueh 1981). The question arose later whether the effect was caused by GR-mediated suppression of LHR expression. The issue was partially addressed by Parthasarathy and Balasubramanian (2008), who measured mRNA of LHR and LH-binding in purified rat Leydig cells after metopyrone induced corticosterone deficiency and subsequent corticosterone replacement. In contrast to previous authors, they did not find significant changes in LH mRNA expression, but it should be stressed that they did not measured the single effect of GCs on LHR mRNA, but only the effect of 
induced GC deficiency. Thus the question remains open and further studies are needed to confirm definitely if the expression of LHR is inhibited by corticoids.

\section{Effect of glucocorticoids on testicular steroidogenesis}

A number of studies dealt with various aspects of GC effect on Leydig cell steroidogenesis. A decrease of testosterone production after GC treatment was observed already by above mentioned authors (Bambino and Hsueh 1981). In their next work using primary cultures from rat testicular cells they compared the inhibitory effect of GC on other steroid precursors in testosterone biosynthesis, which declined in the order androstenedione $(80 \%$ decrease $)$ to $17 \alpha$-hydroxyprogesterone (57\%), with a lesser effect on progesterone production ( $28 \%$ decrease) and no effect on pregnenolone production (Welsh et al. 1982). Later studies on rats definitely proved direct inhibitory effect of $\mathrm{GC}$ on expression on two enzymes of testosterone biosynthesis, namely $3 \beta-$ and 17\%-hydroxysteroid dehydrogenases at their mRNA level (Badrinarayanan et al. 2006).

The effect of glucocorticoid on enzymatic activity and expression of genes encoding for androgen biosynthetic enzymes was also studied in progenitor Leydig cells from 21-day-old rats, which differ from adult Leydig cells in many aspects. The activity of three mitochondrial enzymes of androgen biosynthesis, namely cholesterol side chain cleavage enzyme,

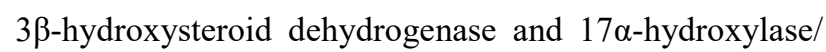
20-lyase plus one androgen metabolizing enzyme, $5 \alpha$-reductase, were measured, along with their protein expression. For the first time they also measured expression of steroid acute regulatory protein (StAR), mediating cholesterol transport across the inner mitochondrial membrane. Generally, GCs decreased activity and expression of the enzymes, though in different way than in adult cells. The effects were inhibited by GR antagonist mifepristone (RU486) confirming GR mediation (Xiao et al. 2010).

Let us mention here a rapid decrease of testosterone production following immobilization stress of mice. In the experiment of Dong et al. (2004), no effect on LH levels was observed within $6 \mathrm{~h}$ after stress in contrast to rapid decrease of testosterone within 30 min, accompanied with a decrease of intracellular cAMP. On the other hand, the reduction of testosterone was reversed by GR antagonist RU486, suggesting a nongenomic mechanism via putative membrane located glucocorticoid receptors.

\section{Regulation of an access of glucocorticoid to its target cells in the testis}

Actual concentration of glucocorticoids and their access to their target tissue is controlled by activity of local microsomal enzyme 11 $\beta$-hydroxysteroid dehydrogenase (11ß-HSD), catalyzing oxidoreduction (interconversion) of cortisol or corticosterone to their biologically inactive 11-oxo metabolites. The enzyme

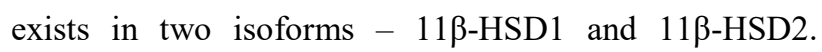
$11 \beta$-HSD1 functions in both directions (oxidation or reduction) using NADPH/NADP+ as cofactors, while 11ß-HSD2 possess exclusively oxidative activity with $\mathrm{NAD}+$ as a cofactor. $11 \beta$-HSD1 is ubiquitous, being abundant especially in liver, 11ß-HSD2 occurs selectively in several tissues as in kidney and also in the testis (Quinkler et al. 2001, Sandeep and Walker 2001, Wang et al. 2019, Šimůnková et al. 2011, Ergang et al. 2014, Máčová et al. 2015). Both isoforms are thus present in the testicular Leydig cells but 11ß-HSD2 contribution to regulate active corticoid access is much lower than that of $11 \beta$-HSD1 (Ge et al. 2005).

The studies with animals and tissue cultures showed that the mechanism used by $11 \beta$-HSD 1 in the liver differs from that operating in Leydig cells. In the former its reductive activity is governed by actual availability of NADPH, generated by hexose-6-phosphate dehydrogenase with glucose-6-phosphate as a substrate. In Leydig cells $11 \beta$-HSD1 is coupled with another

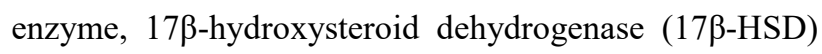
mentioned above. Both enzymes are localized in smooth endoplasmic reticulum membrane. The testosterone precursor androstenedione and NADPH are used by $17 \beta$-HSD1 to generate NADP+, enabling $11 \beta$-HSD1 to function as an oxidase by oxidation of corticosterone to inactive 11-dehydrocorticosterone (Hu et al. 2008).

\section{Do GCs affect Leydig cells apoptosis?}

With respect to well-known promotion of cell apoptosis by GCs and predominantly harmful effects of GCs on Leydig cells function it was of interest, whether the excessive glucocorticoid stimulation also affects total Leydig cell numbers through induction of apoptosis and if so, by which mechanism (Hardy et al. 2005). Studies 
from the same author's group using cultured Leydig cells from adrenalectomized rats proved an increase of Fas Ligand and Fas receptor protein, the key players in starting caspase signaling cascade, characteristic for inner apoptotic pathway, following corticosterone administration. Small DNA fragments typical for apoptosis were seen in Leydig cells as well and addition of a specific caspase inhibitor, Ac-DEVD-CHO led to suppression of apoptosis (Gao et al. 2003). Further studies in vivo using chronically stressed rat model brought clear evidence that GCs induced apoptosis proceeded via glucocorticoid receptors and thus a genomic mechanism takes place here (Chen et al. 2012). Blockade of intratesticular glucocorticoid receptors diminished proapoptotic action without affecting antiapoptotic effects (Andric et al. 2013).

\section{Conclusions}

In the review we have shown how glucocorticoids affect testicular steroidogenesis in the light of recent knowledge of the mechanisms operating at individual levels of hypothalamo-pituitary-gonadal axis. The main ways responsible for the final GC effect are the following: through their receptors in hypothalamus, gonadotropes and in the Leydig cells, GC affect gonadoliberin and LH synthesis and release, and the expression and function of steroidogenic enzymes. In addition, glucocorticoid access to its target cells in the testis is controlled by activity of local enzyme $11 \beta$-hydroxysteroid dehydrogenase. The other effects include so far not clearly evidenced reduction of the number of LH receptors on the membrane of Leydig cells and promotion of Leydig cell apoptosis. Most results have been obtained on animal models and some also by using tissue cultures, but they are valuable also for human medicine since glucocorticoids belong to mass-used therapeutics. We did not review here the effects of glucocorticoid treatment on spermatogenesis and sperm function, which however, is tightly bound to testicular steroidogenesis.

\section{Conflict of Interest}

There is no conflict of interest.

\section{Acknowledgements}

This review was supported by Ministry of Health CR, RVO (Institute of Endocrinology - EU, 00023761).

\section{Abbreviations}

LH - luteinizing hormone, FSH - follicle stimulating hormone, hCG - human chorionic gonadotropin, NADPH - nicotinamide adenine dinucleotide phosphate.

\section{References}

ACEVEDO-RODRIGUEZ A, KAUFFMAN AS, CHERRINGTON BD, BORGES CS, ROEPKE TA, LACONI M: Emerging insights into hypothalamic-pituitary-gonadal axis regulation and interaction with stress signalling. J Neuroendocrinol 30: e12590, 2018. https://doi.org/10.1111/jne.12590

ANDRIC SA, KOJIC Z, BJELIC MM, MIHAJLOVIC AI, BABURSKI AZ, SOKANOVIC SJ, JANJIC MM, STOJKOV NJ, STOJILKOVIC SS, KOSTIC TS: The opposite roles of glucocorticoid and $\alpha 1$-adrenergic receptors in stress triggered apoptosis of rat Leydig cells. Am J Physiol Endocrinol Metab 304: E51-E59, 2013. https://doi.org/10.1152/ajpendo.00443.2012

BADRINARAYANAN R, RENGARAJAN S, NITHYA P, BALASUBRAMANIAN K: Corticosterone impairs the mRNA expression and activity of 3beta- and 17beta-hydroxysteroid dehydrogenases in adult rat Leydig cells. Biochem Cell Biol 84: 745-754, 2006. https://doi.org/10.1139/o06-074

BAMBINO TH, HSUEH AJ: Direct inhibitory effect of glucocorticoids upon testicular luteinizing hormone receptor and steroidogenesis in vivo and in vitro. Endocrinology 108: 2142-2148, 1981. https://doi.org/10.1210/endo108-6-2142

BREEN KM, MELLON PL: Influence of stress-induced intermediates on gonadotropin gene expression in gonadotrope cells. Mol Cell Endocrinol 385: 71-77, 2014. https://doi.org/10.1016/j.mce.2013.08.014

BREEN KM, THACKRAY VG, HSU T, MAK-MCCULLY RA, COSS D, MELLON PL: Stress levels of glucocorticoids inhibit LH $\beta$-subunit gene expression in gonadotrope cells. Mol Endocrinol 26: 1716-1731, 2012. https://doi.org/10.1210/me.2011-1327 
BRISKI KP, VOGEL KL, MCINTYRE AR: The antiglucocorticoid, RU486, attenuates stress-induced decreases in plasma-luteinizing hormone concentrations in male rats. Neuroendocrinology 61: 638-645, 1995. https://doi.org/10.1159/000126890

CHEN Y, WANG Q, WANG FF, GAO HB, ZHANG P: Stress induces glucocorticoid-mediated apoptosis of rat Leydig cells in vivo. Stress 15: 74-84, 2012. https://doi.org/10.3109/10253890.2011.585188

DONG Q, SALVA A, SOTTAS CM, NIU E, HOLMES M, HARDY MP: Rapid glucocorticoid mediation of suppressed testosterone biosynthesis in male mice subjected to immobilization stress. J Androl 25: 973-981, 2004. https://doi.org/10.1002/j.1939-4640.2004.tb03170.x

ERGANG P, KUŽELOVÁ A, SOTÁK M, KLUSOŇOVÁ P, MAKAL J, PÁCHA J: Distinct effect of stress on 11 betahydroxysteroid dehydrogenase type 1 and corticosteroid receptors in dorsal and ventral hippocampus. Physiol Res 63: 255-261, 2014. https://doi.org/10.33549/physiolres.932588

GAO HB, TONG MH, HU YQ, YOU HY, GUO QS, GE RS, HARDY MP: Mechanisms of glucocorticoid-induced Leydig cell apoptosis. Mol Cell Endocrinol 199: 153-163, 2003. https://doi.org/10.1016/S03037207(02)00290-3

GE RS, DONG Q, NIU EM, SOTTAS CM, HARDY DO, CATTERALL JF, LATIF SA, MORRIS DJ, HARDY MP: 11 beta-hydroxysteroid dehydrogenase 2 in rat Leydig cells: its role in blunting glucocorticoid action at physiological levels of substrate. Endocrinology 146: 2657-2664, 2005. https://doi.org/10.1210/en.2005-0046

HARDY MP, GAO HB, DONG Q, GE R, WANG Q, CHAI WR, FENG X, SOTTAS C: Stress hormone and male reproductive function. Cell Tissue Res 322: 147-153, 2005. https://doi.org/10.1007/s00441-005-0006-2

HU GX, LIAN QQ, LIN H, LATIF SA, MORRIS DJ, HARDY MP, GE RS: Rapid mechanisms of glucocorticoid signaling in the Leydig cell. Steroids 73: 1018-1024, 2008. https://doi.org/10.1016/j.steroids.2007.12.020

IWASA T, MATSUZAKI T, YANO K, MAYILA Y, IRAHARA M: The roles of kisspeptin and gonadotropin inhibitory hormone in stress-induced reproductive disorders. Endocr J 65: 133-140, 2018. https://doi.org/10.1507/endocrj.EJ18-0026

MÁČOVÁ L, SOSVOROVÁ L, VÍTKŮ J, BIČÍKOVÁ M, HILL M, ZAMRAZILOVÁ H, SEDLÁČKOVÁ B, STÁRKA L: Steroid hormones related to 11 beta-hydroxysteroid dehydrogenase type 1 in treated obesity. Physiol Res 64 (Suppl 2): S121-S133, 2015. https://doi.org/10.33549/physiolres.933073

NARGUND VH: Effects of psychological stress on male fertility. Nat Rev Urol 12: 373-382, 2015. https://doi.org/10.1038/nrurol.2015.112

OPSTAD PK: The hypothalamo-pituitary regulation of androgen secretion in young men after prolonged physical stress combined with energy and sleep deprivation. Acta Endocrinol (Copenh) 127: 231-236, 1992. https://doi.org/10.1530/acta.0.1270231

OYOLA MG, HANDA RJ: Hypothalamic-pituitary-adrenal and hypothalamic-pituitary-gonadal axes: sex differences in regulation of stress responsivity. Stress 20: 476-494, 2017. https://doi.org/10.1080/10253890.2017.1369523

PARTHASARATHY C, BALASUBRAMANIAN K: Differential effect of corticosterone deficiency on the expression of LH, prolactin and insulin receptors on rat Leydig cells. Mol Cell Endocrinol 285: 34-42, 2008. https://doi.org/10.1016/j.mce.2008.01.020

QUINKLER M, OELKERS W, DIEDERICH S: Clinical implications of glucocorticoid metabolism by 11 betahydroxysteroid dehydrogenases in target tissues. Eur J Endocrinol 144: 87-97, 2001. https://doi.org/10.1530/eje.0.1440087

SAKAKURA M, TAKEBE K, NAKAGAWA S: Inhibition of luteinizing hormone secretion induced by synthetic LRH by long-term treatment with glucocorticoids in human subjects. J Clin Endocrinol Metab 40: 774-779, 1975. https://doi.org/10.1210/jcem-40-5-774

SANDEEP TC, WALKER BR: Pathophysiology of modulation of local glucocorticoid levels by 11 beta-hydroxysteroid dehydrogenases. Trends Endocrinol Metab 12: 446-453, 2001. https://doi.org/10.1016/S1043-2760(01)00499-4

ŠIMŮNKOVÁ K, HAMPL R, HILL M, KŘÍŽ L, VRBÍKOVÁ J, KVASNIČKOVÁ H, VONDRA K: Evaluation of hepatic 11 beta-hydroxysteroid dehydrogenase activity by cortisone acetate test in young adults with diabetes mellitus type 1. Physiol Res 60: 263-270, 2011. https://doi.org/10.33549/physiolres.932079 
UBUKA T, SON YL, TOBARI Y, NARIHIRO M, BENTLEY GE, KRIEGSFELD LJ, TSUTSUI K: Central and direct regulation of testicular activity by gonadotropin-inhibitory hormone and its receptor. Front Endocrinol (Lausanne) 5: 8, 2014. https://doi.org/10.3389/fendo.2014.00008

WANG Y, LI H, ZHU Q, LI X, LIN Z, GE RS: The cross talk of adrenal and Leydig cell steroids in Leydig cells. J Steroid Biochem Mol Biol 192: 105386, 2019. https://doi.org/10.1016/j.jsbmb.2019.105386

WELSH TH JR, BAMBINO TH, HSUEH AJ: Mechanism of glucocorticoid-induced suppression of testicular androgen biosynthesis in vitro. Biol Reprod 27: 1138-1146, 1982. https://doi.org/10.1095/biolreprod27.5.1138

WHIRLEDGE S, CIDLOWSKI JA: Glucocorticoids, stress, and fertility. Minerva Endocrinol 35: 109-125, 2010.

WITORSCH RJ: Effects of elevated glucocorticoids on reproduction and development: relevance to endocrine disruptor screening. Crit Rev Toxicol 46: 420-436, 2016. https://doi.org/10.3109/10408444.2016.1140718

XIAO YC, HUANG YD, HARDY DO, LI XK, GE RS: Glucocorticoid suppresses steroidogenesis in rat progenitor Leydig cells. J Androl 31: 365-371, 2010. https://doi.org/10.2164/jandrol.109.009019 